\title{
Prognostic Factors and Local Treatment Modalities of Small-Cell Carcinoma of the Cervix: An Analysis According to the International Federation of Gynecology and Obstetrics Stage [Corrigendum]
}

\author{
Huang R, Gan Q, Cheng J. Cancer Manag Res. \\ 2020;12:3445-3456.
}

The authors have advised the affiliation and correspondence address on page 3445 is incorrect. The correct affiliation should read "Department of Obstetrics and Gynecology, Shanghai East Hospital, Tongji University School of Medicine,
Shanghai 200120, People's Republic of China" and the correspondence address should read "Department of Obstetrics and Gynecology, Shanghai East Hospital, Tongji University School of Medicine, 150 Jimo Avenue, Shanghai 200120, People's Republic of China".

The authors apologize for these errors.

\section{Publish your work in this journal}

Cancer Management and Research is an international, peer-reviewed open access journal focusing on cancer research and the optimal use of preventative and integrated treatment interventions to achieve improved outcomes, enhanced survival and quality of life for the cancer patient.
The manuscript management system is completely online and includes a very quick and fair peer-review system, which is all easy to use. Visit http://www.dovepress.com/testimonials.php to read real quotes from published authors. 